\title{
Production of DMS from dissolved DMSP in axenic cultures of the marine phytoplankton species Phaeocystis sp.
}

\author{
J. Stefels, W. H. M. van Boekel \\ Dept of Marine Biology, University of Groningen, PO Box 14, 9750 AA Haren, The Netherlands
}

\begin{abstract}
In the marine environment, production of dimethylsulfide (DMS) from dissolved dimethylsulfoniopropionate $\left(\mathrm{DMSP}_{\mathrm{d}}\right.$ ) - an algal osmolyte - is thought to occur mainly through bacterial activity. We have investigated the possibility that phytoplankton cells convert DMSP $d$ into DMS, using axenic batch cultures of Phaeocystis sp. at different growth stages. DMSP ${ }_{d}$ added to the medium was converted enzymatically to DMS by Phaeocystis sp. A culture in the exponential growth phase displayed Michaelis-Menten type kinetics for $\mathrm{DMSP}_{\mathrm{d}}$ conversion, yielding an apparent $K_{\mathrm{m}}$ value for DMSP of $11.7 \pm 3.1 \mu \mathrm{M}$ and a $V_{\max }$ value of $3.05 \pm 0.48 \mathrm{nmol}$ DMS produced $\min ^{-1}\left(10^{6} \text { cells }\right)^{-1}$ DMSP $_{d}$ conversion rates declined during the transition from exponential to stationary growth phase, at least partly due to a diminished overall affinity of the enzyme system(s) involved in DMSP conversion. No evidence was obtained for accumulation of inhibiting substances in the medium. Intracellular DMSP concentrations in Phaeocystis sp. batch cultures increased from $71 \mathrm{mM}$ in exponential-phase cells to ca $150 \mathrm{mM}$ in stationary-phase cells. DMS and DMSP ${ }_{d}$ concentrations in the culture remained very low during the exponential growth phase. DMS production started in early stationary phase. In a senescent culture DMSP $_{d}$ appeared when cell numbers started to decline. DMSP production in this culture continued even when cell numbers declined. In completely lysed batch cultures some $25 \%$ of total DMSP remained as DMSP ${ }_{d}$. The results indicate that Phaeocystis sp. may contribute significantly to DMS production from DMSP $P_{d}$ during bloom situations in the field.
\end{abstract}

\section{INTRODUCTION}

In recent years, dimethylsulfide (DMS) production and consumption processes in marine environments as well as the flux of DMS to the atmosphere have been studied intensively (see reviews by Cooper \& Matrai 1989, Taylor \& Kiene 1989, Andreae 1990, Kelly \& Smith 1990, Fitzgerald 1991). This interest is caused by the realization that DMS may be involved in the biological regulation of the climate: 90 to $95 \%$ of the aerosols found above remote oceans consist of non-seasalt sulfate (nss sulfate) that is formed by gas-to-particle conversion of the oxidation products of organosulfur gases (principally DMS). Aerosols serve as cloud condensation nuclei (CCN). The amount of DMS released into the atmosphere influences the number of $\mathrm{CCN}$ and thereby cloud droplet size, cloud albedo and, consequently, climate. Charlson et al. (1987) presented a theoretical model in which they suggested that in this way oceanic phytoplankton could counteract greenhouse warming. The strength of this feedback mechanism is still under discussion (Schwartz 1988, Foley et al. 1991). Recently, evidence has been presented for a correlation between the DMS and nss sulfate concentrations and the number of $\mathrm{CCN}$ in the atmosphere (Ayers \& Gras 1991, Ayers et al. 1991, Bürgermeister \& Georgii 1991, Prospero et al. 1991).

The flux of DMS from the ocean into the atmosphere is determined by its concentration in the water, which is the result of several production and removal processes. In seawater DMS is produced from dimethylsulfoniopropionate (DMSP), a compound that is found in marine macroalgae (Reed 1983, Karsten et al. 1990) and a number of phytoplankton species from different taxonomical groups (Keller et al. 1989). The function of DMSP in the cell is not fully understood, but it has 
been suggested that it acts as an osmolyte (Vairavamurthy et al. 1985, Dickson \& Kirst 1987 a, b), cryoprotectant (Kirst et al. 1991) or methyl donor (Ishida 1968). Conversion of DMSP into DMS and acrylic acid is thought to occur mainly after its release from the cells. In seawater, chemical conversion through hydroxide decomposition is negligible: at $\mathrm{pH} 8.2$ and $10{ }^{\circ} \mathrm{C}$ dissolved DMSP (DMSP d has a chemical half-life of 8 yr (Dacey \& Blough 1987). Most. DMSP is cleaved through enzymatic activity, but little is known about the mechanisms involved. A specific enzyme, DMSPlyase, has been found in crude extracts from the macroalga Polysiphonia lanosa (Cantoni \& Anderson 1956). Ishida (1968) was able to isolate a crude enzyme preparation from extracts of the heterotrophic dinoflagellate Gyrodinium cohnii. Enzymatic DMSP conversion has also been found in cultures and natural populations of bacteria (Dacey \& Blough 1987, Kiene 1990, 1992, Kiene \& Service 1991). Grazing of zooplankton on algae stimulated DMS production in the water. It is not clear whether this was due to enzymatic conversion of DMSP in the guts of the zooplankton or to increased release of DMSP into the water (Dacey \& Wakeham 1986). Removal processes acting on the DMS pool in the water are the flux to the atmosphere (Liss \& Slater 1974), as well as the consumption of DMS by bacteria (Taylor \& Kiene 1989, Kiene \& Bates 1990 , Kiene 1992). Photochemical oxidation of DMS to DMSO may also form a sink, especially in coastal waters (Brimblecombe \& Shooter 1986).

Until now, attempts to quantify the production and consumption of DMS have been scarce. Kiene (1990, 1992) and Kiene \& Service (1991) suggested that bacteria are most important in DMS production from DMSP $_{d}$. Kiene \& Bates (1990) found that in the eastern Pacific Ocean microbial DMS consumption was more than 10 times faster than the flux of DMS to the atmosphere. Evidence for an important role of phytoplankton itself in the actual conversion of DMSP to DMS is lacking. Wakeham \& Dacey (1989) estimated the turnover of intracellular DMSP in microalgae to be $1 \%$ per day. The possibility that phytoplankton are able to produce DMS from extracellular DMSP - released in the water by e.g. algal cell lysis or sloppy feeding by zooplankton - has not been investigated. Still, this may be an important route of DMS production during algal blooms. Experiments with natural phytoplankton assemblages suggest that most DMSP will be released in the water at the end of the bloom when algal biomass is at its maximum (Nguyen et al. 1988). Bacterial biomass is often still low at that time (Billen et al. 1990, van Boekel et al. 1992). If the algal DMSP degradation is significant and bacterial activity is low, then a greater fraction of the DMSP sulfur could escape to the atmosphere, because (1) bacterial demethylation of DMSP will not compete with the DMS production pathway, resulting in more DMS, and (2) there will be little or no biological DMS consumption.

The possible algal conversion of $\mathrm{DMSP}_{\mathrm{d}}$ into DMS was investigated using Phaeocystis sp. as model organism. This bloom-forming phytoplankton species occurs in Arctic and Antarctic oceans and in some temperate coastal waters, and is one of the most important DMSP producers (Barnard et al. 1984, Turner et al. 1989, Gibson et al. 1990). The objective of this study was to establish a relationship between DMSP $\mathrm{d}_{\mathrm{d}}$ concentration and DMS production by Phaeocystis sp. cells under different physiological conditions. We also followed DMS production in the senescent phase of a Phaeocystis sp. batch culture, in order to obtain an indication of the processes involved in DMSP breakdown during the decline of a natural Phaeocystis sp. bloom.

\section{MATERIALS AND METHODS}

Algal strain. An axenic strain of Phaeocystis sp (strain K) isolated from the North Sea was used in all experiments.

Culturing conditions. The culture medium was as described by Veldhuis \& Admiraal (1987) with the exception that nitrate was the only nitrogen source. Phaeocystis sp. cultures were incubated in $1 \mathrm{l}$ serum bottles placed on a rolling device $(3 \mathrm{rpm})$ at $10^{\circ} \mathrm{C}$ and light intensity of $85 \mu \mathrm{E} \mathrm{m}^{-2} \mathrm{~s}^{-1}$ in a $14 \mathrm{~h}$ light : $10 \mathrm{~h}$ dark cycle.

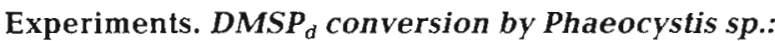
The conversion of DMSP was determined by the increase in DMS concentration in the medium. Samples for determination of the $\mathrm{DMSP}_{d}$ conversion rate were taken from a batch culture at the end of the exponential phase. Activity was measured in an untreated sample, a sample filtered through a GF/F Whatman filter and in a sample heated for $45 \mathrm{~min}$ at $60^{\circ} \mathrm{C}$ and then brought back to $20^{\circ} \mathrm{C}$ to destroy enzymatic activity. Abiotic conversion of $\mathrm{DMSP}_{\mathrm{d}}$ was examined in fresh culture medium adjusted to the $\mathrm{pH}$ of the Phaeocystis sp. culture ( $\mathrm{pH}$ 9.1). DMSP (2 mM stock in $\mathrm{HCl}, \mathrm{pH} 2.5$ ) was added to all samples to a final concentration of $10 \mu \mathrm{M}$. DMS production in these samples and in a culture sample without added DMSP was measured over time. Exact procedures for DMS analysis are described below.

Effect of DMSP $P_{d}$ concentration and Phaeocystis sp. growth phase on DMSP conversion: The relation between DMSP $_{d}$ concentration (0 to $\left.100 \mu \mathrm{M}\right)$ and DMS production rate by Phaeocystis sp. batch culture cells was determined with samples from various stages of growth. Exact procedures are described below. Simultaneously, samples were taken for algal cell 
counts, bacterial cell counts (to check for contamination), and the concentrations of DMS, DMSP and particulate DMSP (DMSP $)$. Abiotic conversion of DMSP in the experiment was measured using fresh medium.

Causes for changes in DMSP $_{d}$ conversion rate: To check for the possible accumulation of inhibitory compounds, part of an end-exponential phase Phaeocystis $\mathrm{sp}$. culture was filtered by gravitation over a $0.45 \mu \mathrm{m}$ cellulose acetate filter. The cells retained on the filter were resuspended in freshly prepared medium. Samples were taken from this culture and from an untreated culture to determine $\mathrm{DMSP}_{\mathrm{d}}$ conversion rates at 10 and $100 \mu \mathrm{MDMSP} \mathrm{d}_{\mathrm{d}}$. Cell counts were carried out to correct for cell loss during filtration. Possible undersaturation of the enzyme in dense cultures was tested by diluting part of an end-exponential phase culture 5 -fold with filtered medium from the same culture, and measuring DMSP $_{\mathrm{d}}$ conversion rate in both diluted and

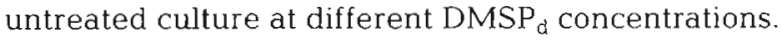

Fate of DMSP in a decaying Phaeocystis sp. culture: In a senescent batch culture, the concentrations of DMS, DMSP $\mathrm{d}$ and DMSP , and Phaeocystis sp. cell number, were followed.

DMS and DMSP analysis. All DMS measurements were carried out using $20 \mathrm{ml}$ samples stored in $60 \mathrm{ml}$ glass vials stoppered with teflon Mininert valves. Vials were placed in the dark at $20^{\circ} \mathrm{C}$ in a constant-temperature waterbath. DMS was allowed to equilibrate with the headspace for $30 \mathrm{~min}$. For DMSP analysis, $0.52 \mathrm{ml}$ $10 \mathrm{M} \mathrm{NaOH}$ was added to a $20 \mathrm{ml}$ sample in a $60 \mathrm{ml}$ vial (final $\mathrm{pH}$ 13), and quickly stoppered with a Mininert valve. The sample was allowed to react for at least $5 \mathrm{~h}$ in the dark at $20^{\circ} \mathrm{C}$. At pH 13, DMSP is decomposed quantitatively into DMS and acrylate (White 1982, Dacey \& Blough 1987). DMS and total DMSP $\left(\mathrm{DMSP}_{\mathrm{t}}\right.$ ) were measured in unfiltered samples. DMSP was measured in samples which had been filtered gently over GF/F Whatman filters. Only gravity filtration was used to prevent cell rupture. The filtration procedure caused loss of DMS; it proved to be large but reproducible $(37.5 \pm 4.4 \%, n=4)$, so correction factors could be applied. Control experiments with DMSP standards showed no retention of $\mathrm{DMSP}_{d}$ on the filter. DMSP $_{t}$ and DMSP $_{d}$ were corrected for the DMS present in the samples. DMSP $P_{p}$ was calculated as the difference between DMSP $P_{t}$ and DMSP $_{d}$.

For measurement of the DMS production rate at different concentrations of DMSP ${ }_{\alpha}, 20 \mathrm{ml}$ culture samples were transferred to vials after which DMSP was added from stock solutions and the vials were stoppered with Mininert valves. Two stock solutions in $\mathrm{HCl}(\mathrm{pH} 2.5)$ were used: $2 \mathrm{mM}$ for final DMSP concentrations up to $10 \mu \mathrm{M}$ and $20 \mathrm{mM}$ for final DMSP concentrations up to $100 \mu \mathrm{M}$; added volumes never exceded $100 \mu \mathrm{l}$. Vials were stored in the dark at $20^{\circ} \mathrm{C}$, and samples for
DMS analysis were taken from them at regular intervals.

DMS analysis was carried out on a Varian 3600 gas chromatograph equipped with a sulfur-specific Hall Electrolytic Conductivity Detector (ELCD) and a $5 \mathrm{~m}$ long, wide bore DB5 column. Methanol was used as detector solvent. Analyses were performed isothermally at $40^{\circ} \mathrm{C}$, with a He carrier gas flow of $10 \mathrm{ml}$ $\mathrm{min}^{-1}$. Under these conditions DMS evolves after $1 \mathrm{~min}$; the detection limit was $5 \mathrm{pg}$ DMS-S. Due to the very low detection limit of the ELCD it was possible to measure DMS concentration in the culture samples by injecting $100 \mu \mathrm{l}$ headspace samples from the vials directly on column. For calculation of DMS concentrations a calibration curve was made, using standard stocks in the range of 0 to $10 \mu \mathrm{M}$ DMS (the detection limit of $5 \mathrm{pg}$ DMS-S corresponded with a stock solution of ca $0.02 \mu \mathrm{M}$ DMSP). Since gravimetric preparation of DMS stocks is subject to errors due to the volatile nature of DMS, standards were made using DMSP (obtained from Research Plus, Inc., USA). A primary standard of $2 \mathrm{mM}$ DMSP was prepared in $\mathrm{HCl}(\mathrm{pH} 2.5)$ and stored at $4{ }^{\circ} \mathrm{C}$. A secondary standard of $20 \mu \mathrm{M}$ DMSP and the DMSP working standards were prepared in sterilized artificial seawater $(20 \mathrm{ml}$ in $60 \mathrm{ml}$ vials $)$ and converted to DMS through addition of $0.52 \mathrm{ml} 10 \mathrm{M}$ $\mathrm{NaOH}$. Working standards were stored under the same conditions as culture samples and were found to be stable for at least $2 \mathrm{wk}$.

Biological analysis. Phaeocystis sp. cells were counted using the Utermöhl sedimentation technique (Utermöhl 1958) after fixation of samples with buffered Lugol's solution.

Cultures were examined regularly for bacterial contamination with Hoechst dye no. 33258, using fluorescence microscopy (Paul 1982). No bacterial contamination was detected during the experiments.

\section{RESULTS}

\section{DMSP $_{d}$ conversion by Phaeocystis sp.}

The possible conversion of DMSP $_{d}$ to DMS by Phaeocystis sp. cells was examined by adding $10 \mu \mathrm{M}$ DMSP to a sample from an end-exponential phase Phaeocystis sp. culture (cell number $=3 \times 10^{8} \mathrm{l}^{-1}$ ). As shown in Fig. 1 this clearly resulted in DMS production. Some DMS production (13\% of total) was found in the medium, but most activity was associated with the cells. In early-exponential phase batch cultures of Phaeocystis sp. the activity in the medium was negligible (not shown). No significant DMS production was found in a culture sample that had been heated prior to DMSP addition, indicating the enzymatic nature of the 


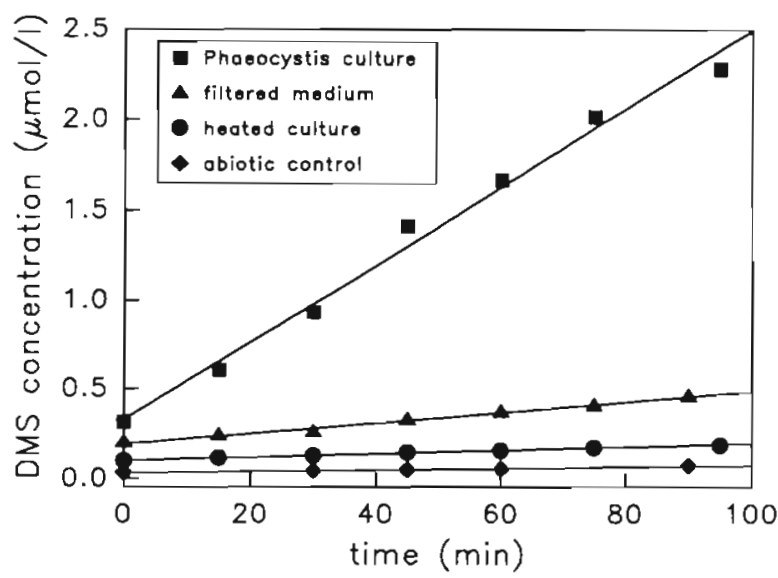

Fig. 1 Phaeocystis sp. DMS concentration as a function of time after addition of $10 \mu \mathrm{M}$ DMSP to a batch culture sample from the end-exponential growth phase $\left(3 \times 10^{8} \mathrm{cells}^{-1}\right)$, the filtered medium, a heated culture and fresh medium (abiotic control)

reaction. In a culture sample without added DMSP, there was no DMS production either (not shown), nor did abiotic DMS production occur.

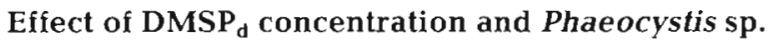 growth phase on DMSP conversion}

In the batch culture used for this experiment the cell number increased exponentially until Day 8 and remained constant thereafter (Fig. 2). DMS production at DMSP $_{d}$ concentrations between 0 and $100 \mu \mathrm{M}$ was measured in samples taken from the batch culture on Days $3,7 \& 10$ (Fig. 3). During the early-exponential phase (Day 3) the DMS production rate showed a Michaelis-Menten type relation with the $\mathrm{DMSP}_{d}$ concentration in the medium. Using the direct-linear plot method, a $K_{\mathrm{m}}$-value of $11.7 \mu \mathrm{M} \mathrm{DMSP}_{\mathrm{d}}$ (SD = 3.1,

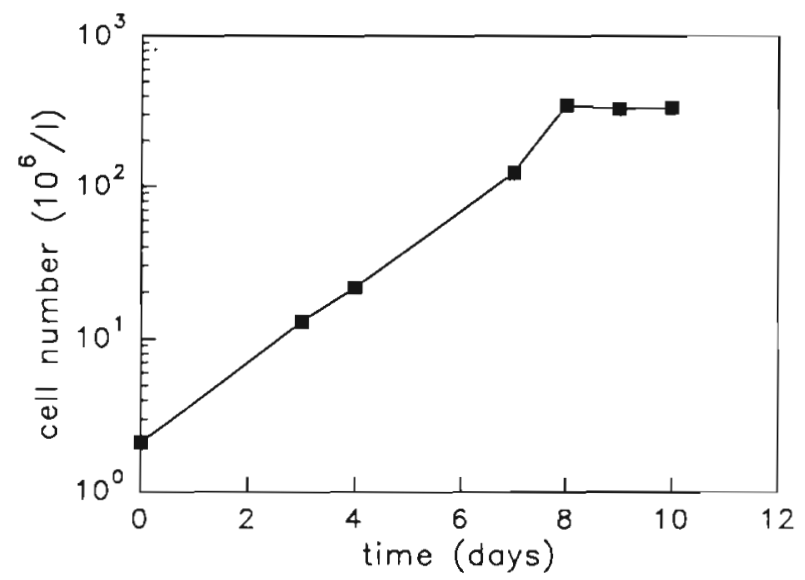

Fig. 2. Phaeocystis sp. Time course of cell number during growth in batch culture (see Fig. 3)

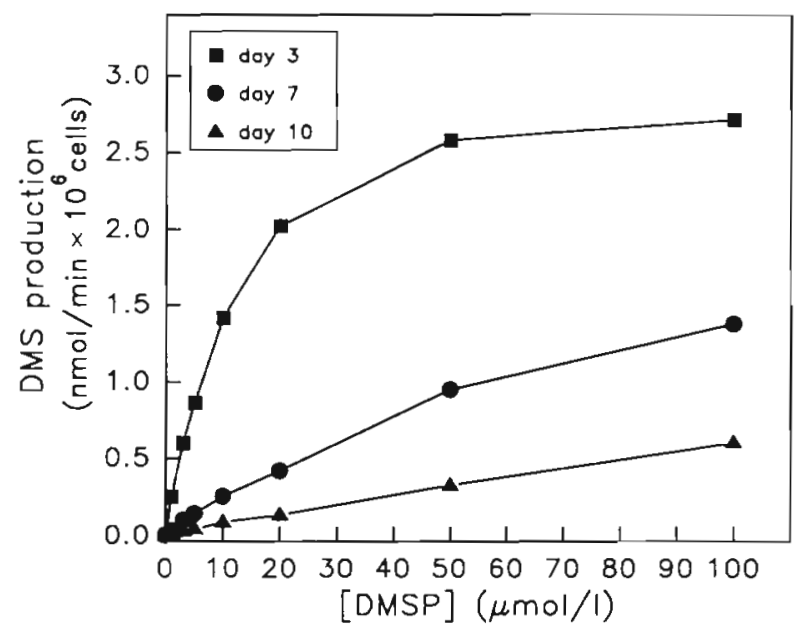

Fig. 3. Phaeocystis sp. Relation between dissolved DMSP concentration and DMS production rate in samples taken on Days 3,7 , and 10 from a batch culture (see Fig. 2)

$\mathrm{n}=21)$ and a $V_{\max }-$ value of $3.05 \mathrm{nmol}$ DMS $\mathrm{min}^{-1}\left(10^{6}\right.$ cells $)^{-1}(\mathrm{SD}=0.48, \mathrm{n}=21$ ) were calculated from these results. At the end of the exponential phase (Day 7) and in the stationary phase (Day 10) DMS production rates (normalized to cell number) declined and the relation with $\mathrm{DMSP}_{d}$ concentration became virtually linear over the range of $\mathrm{DMSP}_{d}$ concentrations used (Fig. 3). Abiotic DMS production was negligible for all DMSP $_{d}$ concentrations used (not shown). In the batch culture itself, DMS and DMSP $P_{d}$ concentrations were low during the exponential phase (Table 1). In the stationary phase DMS accumulated in the medium, while $\mathrm{DMSP}_{d}$ remained at low concentrations. $\mathrm{DMSP}_{\mathrm{p}}$ increased with Phaeocystis sp. cell number to $5.31 \mu \mathrm{M}$. Intracellular DMSP concentrations were calculated using an average cell volume of $113 \mu \mathrm{m}^{3}$ (van Boekel unpubl.). Cell volume did not change during growth. Intracellular DMSP concentration increased more than 2 -fold from $71 \mathrm{mM}$ on Day 3 to $161 \mathrm{mM}$ on Day 7 and remained approximately the same thereafter (Table 1).

\section{Causes for changes in $\mathrm{DMSP}_{\mathrm{d}}$ conversion rate}

The observed changes in DMSP conversion rates in batch cultures could be due to the accumulation of inhibitory compounds in the medium. Stationaryphase Phaeocystis sp. cells (cell number in culture = $3.29 \times 10^{8} \mathrm{l}^{-1}$ ), therefore, were transferred to freshly prepared medium and DMS production measured at 2 DMSP $_{d}$ concentrations. The cells in fresh mediurn showed approximately the same DMS production rates as untreated cells from the same culture (Table 2).

Another possible cause for the changes in DMSP conversion rate could be the increasing cell density in 
Table 1. Phaeocystis sp. DMS and DMSP concentrations in batch culture (cf. Figs. $2 \& 3$ )

\begin{tabular}{|ccccc|}
\hline Day & $\begin{array}{c}\text { DMS } \\
(\mu \mathrm{M})\end{array}$ & $\begin{array}{c}\text { Dissolved } \\
\text { DMSP }(\mu \mathrm{M})\end{array}$ & $\begin{array}{c}\text { Particulate } \\
\text { DMSP }(\mu \mathrm{M})\end{array}$ & $\begin{array}{c}\text { Intracellular } \\
\text { DMSP }(\mathrm{mM})\end{array}$ \\
\hline 3 & 0.06 & 0.02 & 0.10 & 71 \\
7 & 0.22 & 0 & 2.22 & 169 \\
10 & 0.59 & 0.03 & 5.31 & 141 \\
\hline
\end{tabular}

drop. It was of interest to know if the remaining algal activity was able to convert the DMSP released by the cells to DMS. The concentrations of DMS, DMSP $d$, DMSP $_{\mathrm{p}}$ and Phaeocystis sp. cell number were followed from Day 11 onwards in a senescent batch culture. The number of (apparently) normal cells increased until Day 16 and declined sharply thereafter (Fig. 5A). Large numbers of bleached, deformed or broken cells were

Table 2. Phaeocystis sp. Rate of production of DMS from dissolved DMSP added to a batch culture transferred into fresh medium, and to the untreated control culture

\begin{tabular}{|c|c|c|}
\hline \multirow[t]{2}{*}{$\begin{array}{l}\text { DMSP concen- } \\
\text { tration }(\mu \mathrm{M})\end{array}$} & \multicolumn{2}{|c|}{$\begin{array}{c}\text { DMS production rate } \\
{\left[\mathrm{nmol} \mathrm{min}^{-1}\left(10^{6} \text { cells }\right)^{-1}\right]}\end{array}$} \\
\hline & Fresh medium & Untreated \\
\hline 10 & 0.068 & 0.062 \\
\hline 100 & 0.426 & 0.373 \\
\hline
\end{tabular}

the culture. At very high enzyme concentrations and low substrate concentrations part of the enzymes present may remain inactive, causing an underestimation of the conversion rate (Dixon \& Webb 1979). However, a 5-fold dilution of an end-exponential phase Phaeocystis sp. culture (cell number in culture = $93 \times 10^{6} \mathrm{l}^{-1}$ ) did not result in increased DMS production rates, compared to the undiluted control (Fig. 4).

\section{Fate of DMSP in a decaying Phaeocystis sp. culture}

In senescent cultures, intracellular DMSP may be released in the medium upon cell lysis. Since the cell number is decreasing and cells are almost inactive, both cultural and specific DMSP conversion rates may

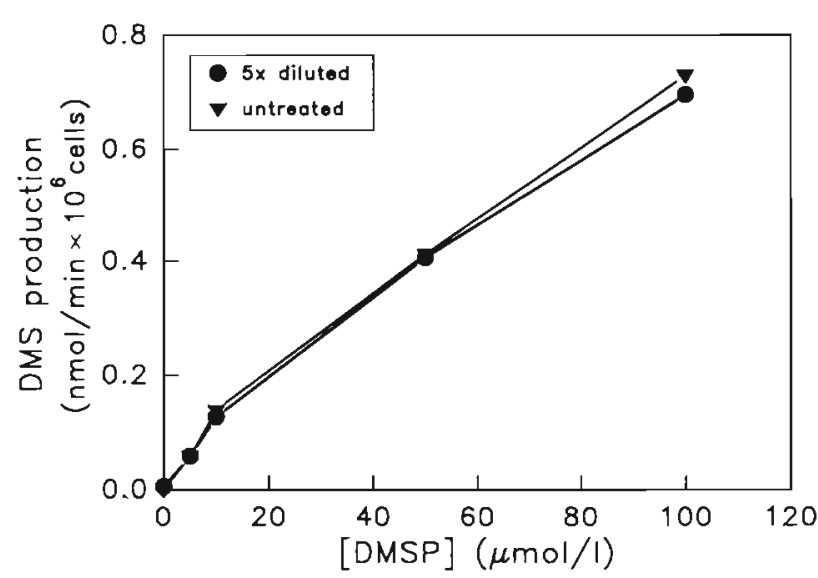

Fig. 4. Phaeocystis sp. Relation between dissolved DMSP concentration and DMS production rate in an untreated and in a 5 -fold diluted batch culture present on Days 18 and 21. DMS accumulated in the culture from Day 14 onwards (Fig. 5B). DMSP $d$ concentration was below $0.17 \mu \mathrm{M}$ until Day 15 and then increased to $\pm 0.4 \mu \mathrm{M}$. DMSP $p$ concentration increased until Day 15 and then declined. Intracellular DMSP concentration (calculated using numbers of normal cells only) remained approximately constant (Table 3). The intracellular DMSP concentration may, however, have declined if deformed cells still contribute to DMSP $_{p}$. The sum of DMS and DMSP continued to increase even in the period after Day 16 when cell num-
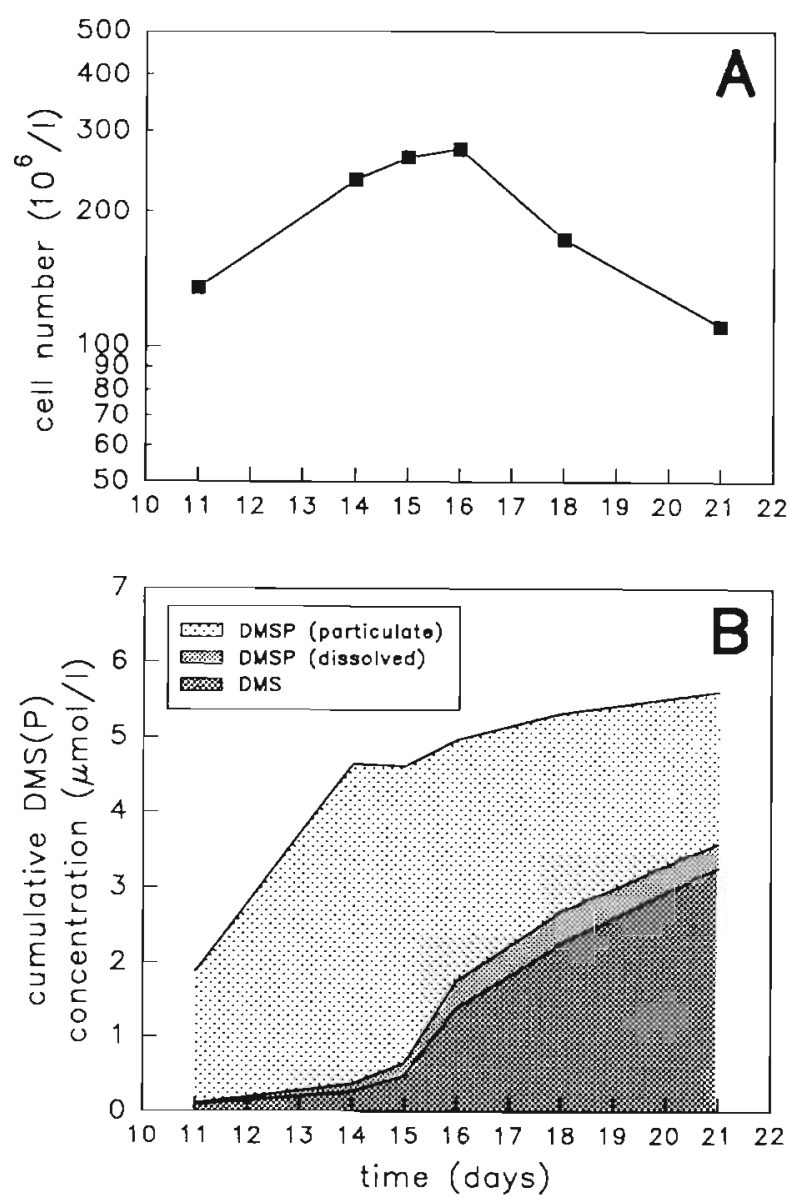

Fig. 5. Phaeocystis sp. Time course of (A) cell number and (B) cumulative concentrations of DMS, dissolved DMSP and particulate DMSP in the medium, during the senescent phase of a batch culture 
Table 3. Phaeocystis sp. DMSP concentrations in cells during the senescent phase (cf. Fig. 5)

\begin{tabular}{|cc|}
\hline Day & Intracellular DMSP (mM) \\
\hline 11 & 116 \\
14 & 160 \\
15 & 133 \\
16 & 103 \\
18 & 134 \\
21 & 163 \\
\hline
\end{tabular}

bers were declining, indicating that intact cells still produced DMSP. Measurements in Phaeocystis sp. cultures that had completely died (all cells lysed) showed that $73 \%$ of total DMSP had been converted to DMS during the senescence phase (not shown).

\section{DISCUSSION}

The results clearly show that Phaeocystis $\mathrm{sp}$. is able to produce DMS from DMSP $_{d}$ added to the medium. DMSP $_{d}$ conversion is the result of an enzymatic activity exhibiting Michaelis-Menten type kinetics during the (mid-) exponential growth phase. This activity is associated with the cells, although in older cultures some activity was detected in the medium. DMSP-lyases have been found in the macroalga Polysiphonia lanosa (Cantoni \& Anderson 1956) and in the heterotrophic dinoflagellate Gyrodinium cohnii (Ishida 1968). The enzyme produced by Phaeocystis sp. might also be a DMSP-lyase, but the possibility that DMSP ${ }_{d}$ conversion is a secondary reaction of an enzyme not specific to DMSP cannot be excluded. The present data do not allow us to conclude whether the enzyme is located intra- or extracellularly. Ishida (1968) found that cells of $G$. cohnii incubated with labelled DMSP did not incorporate radioactivity. If this also holds for Phaeocystis sp., then it would argue for the extracellular location of the enzyme. The production of acrylic acid, which would serve as a bactericide, has been mentioned as an important function of extracellular DMSP conversion by Phaeocystis sp. (Sieburth 1960, Barnard et al. 1984). The antibiotic properties of acrylic acid are, however, rather questionable at the $\mathrm{pH}$ of seawater (Sieburth 1961).

If the enzyme produced by Phaeocystis sp. is intracellularly located it could be involved in the regulation of the DMSP concentration in the cell. Conversion of DMSP $_{d}$ as measured in the experiments described in this paper would then include transport of DMSP $_{d}$ across the cell membrane into the cell and export of the DMS produced. This would necessitate DMSP $P_{d}$ uptake against a strong concentration gradient (1000-fold increase in concentration). Although this seems unlikely, it cannot be excluded. Clearly, these questions concerning the physiological role and location of the enzyme remain to be studied in more detail, also in view of the apparent failure of the enzyme to degrade intracellular DMSP during the exponential growth phase. The decrease in cellular activity observed towards the end-exponential phase of Phaeocystis sp. batch cultures (Fig. 3) was at least partly due to a diminished overall affinity of the enzyme system(s) involved in DMSP conversion. No evidence was obtained for accumulation of inhibitory compounds in the medium or by partial inactivity of the enzyme present (Table 2, Fig. 4). Possibly, changing cell physiology during the transition from the exponential phase to stationary phase led to a decreased rate of DMSP $P_{d}$ transport accross the cell membrane and/or to changes in the regulation mechanism of intracellular DMSP concentrations, resulting in decreased conversion of the DMSP $_{d}$ added to the culture.

The apparent $K_{\mathrm{m}}$ value of $11.7 \mu \mathrm{M}$ found for DMSP conversion of Phaeocystis sp. cells is high compared with DMSP $_{d}$ concentrations normally encountered in the field ( $\left[D M S P_{d}\right]<1 \mu M$ in a Phaeocystis sp.-dominated phytoplankton assemblage in the southern North Sea; Turner et al. 1989). The DMSP-lyase found in Gyrodinium cohnii by Ishida (1968) had a $K_{\mathrm{m}}$ value for DMSP of $1.5 \mathrm{mM}$.

The intracellular DMSP concentration of Phaeocystis sp. increased more than 2-fold during the transition from exponential phase to stationary phase (Table 1). Gröne \& Kirst (1992) found a $75 \%$ increase in intracellular DMSP concentration in N-limited Tetraselmis subcordiformis compared to a culture grown in complete medium. Turner et al. (1988) concluded from experimental and field work that DMSP content increased in Emiliania huxleyi populations due to $\mathrm{N}$-limitation. In both cases the increase of DMSP content was assumed to be a reaction to nitrogen depletion in the cell. Nitrogen-free DMSP was thought to substitute for the nitrogen-containing glycine betaine (a functional analog) that serves as a compatible solute in the osmotic regulation of the cell (Kirst 1989). Gröne \& Kirst (1992) and Turner et al. (1988) did not, however, include P-limited cultures in their experiments. In our opinion the increase in DMSP content might very well be a response to changes in growth rate and physiological state of the cell independently of the kind of limitation the cell experiences. In our experiments the N:P ratio in the medium used was 18 , and, although not measured, phosphate was most probably limiting Phaeocystis sp. biomass development. More research is needed on the relation between DMSP and glycine betaine inside the cell in connection with growth rate and the type of limitation. 
In the senescent Phaeocystis sp. culture $\mathrm{DMSP}_{\mathrm{d}}$ concentration increased after Day 15 (Fig. 5). Also, in totally lysed cultures, $\mathrm{DMSP}_{\mathrm{d}}$ was still present, indicating that the DMSP liberated from cells through cell death was only partly converted to DMS; approximately $25 \%$ remained present as $\mathrm{DMSP}_{\mathrm{c}}$. The total of DMS and DMSP in the senescent culture increased slightly even though cell numbers were declining. This indicates that even in declining populations of Phaeocystis sp. DMSP production can occur. Apart from conversion into DMS, another possible sink of $\mathrm{DMSP}_{\mathrm{d}}$ is demethylation as experienced in natural samples by Kiene \& Service (1991). This was not observed in our experiments with axenic cultures: Fig 5B clearly shows that DMS and DMSP were conservative. Translation of these results to field situations is difficult, since the processes involving DMS(P) that take place in natural Phaeocystis sp. blooms are poorly understood. Still, in field situations, Phaeocystis sp. can be a producer of DMS at all stages of a bloom. We tried to estimate the maximal DMS production by Phaeocystis sp. during natural blooms in the Southern Bight of the North Sea using our data from Fig. 3, a maximal cell number of $50 \times 10^{6} 1^{-1}$ (Cadée \& Hegeman 1986) and a maximal DMSP ${ }_{d}$ concentration of $1.2 \mu \mathrm{M}$ (Turner et al. 1988). These values are most likely to be found during the end-exponential or stationary phase of the Phaeocystis sp. bloom although cell number can reach values over $100 \times 10^{6} \mathrm{l}^{-1}$ (Cadée \& Hegeman 1986) Depending on the growth phase of the Phaeocystis $\mathrm{sp}$ cells, DMS production rates from DMSP $P_{d}$ would range from 0.65 to $14.2 \mathrm{nmol} \mathrm{l}^{-1} \mathrm{~min}^{-1}$ with the higher value found for early-exponential phase cells and the lower value for stationary-phase cells. DMS production rate calculated for the senescent culture after Day 16 (Fig. 5A) was $0.31 \mathrm{nmol} \mathrm{l}^{-1} \mathrm{~min}^{-1}$. These calculated values are in the same range as values found by others in natural systems. Kiene (1990) measured DMS accumulation rates of 0.37 to $0.6 \mathrm{nmol} \mathrm{l}^{-1} \mathrm{~min}^{-1}$ after addition of $0.5 \mu \mathrm{M}$ DMSP to samples from coastal waters off Georgia, USA. Dacey \& Wakeham (1986) found a DMS accumulation rate of $0.14 \mathrm{nmol} \mathrm{l}^{-1} \mathrm{~min}^{-1}$ resulting from zooplankton grazing on DMSP-containing algae.

In addition to DMS production from DMSP, the DMS concentration in the water is subject to consumption processes. Kiene \& Bates (1990) and Kiene (1992), using the chloroform inhibition technique, estimated bacterial DMS consumption rates in Pacific Ocean surface waters to be 0.001 to $0.013 \mathrm{nmol} \mathrm{l}^{-1} \mathrm{~min}^{-1}$. Using the same technique, Kiene \& Service (1991) observed a bacterial DMS consumption rate of approximately $0.002 \mathrm{nmol} \mathrm{l}^{-1} \mathrm{~min}^{-1}$ in estuarine waters off Georgia, USA. It should be mentioned that this was not a bloom situation, and DMS concentrations were only approximately $2 \mathrm{nM}$. At a DMS concentration of $60 \mathrm{nM}$. as found during Phaeocystis sp. blooms (Turner et al. 1989), the DMS consumption rate will probably be higher. However, at the top of a Phaeocystis sp. bloom, bacterial biomass is still low (Billen et al. 1990, van Boekel et al. 1992), while DMS production by algal enzymes is probably maximal. This imbalance of production and consumption might result in relatively high DMS concentrations in the water and consequently in high DMS fluxes to the atmosphere.

In conclusion, the role of Phaeocystis sp. in DMS fluxes in natural systems is probably not restricted to the production of DMSP but also includes direct production of DMS. The actual contribution of Phaeocystis sp. to total DMS production during bloom situations will however have to be measured in the field.

Acknowledgements. The authors thank P. Aernoutse for practical assistance, H. van Gemerden for providing a steady supply of DMSP and L. Dijkhuizen for useful comments. W. W. C. Gieskes is acknowledged for his general support. This study was performed within the framework of the NOP project 'Formation and air/sea exchange of DMS from marine sources', supported by the Dutch government (NOLK/026/90)

\section{LITERATURE CITED}

Andreae, M. O. (1990). Ocean-atmosphere interactions in the global biogeochemical sulfur cycle. Mar. Chem. 30: 1-29

Ayers, G. P., Gras, J. L. (1991). Seasonal relationship between cloud condensation nuclei and aerosol methanesulphonate in marine air. Nature 353: 834-835

Ayers, G. P., Ivey, J. P., Gillett, R. W. (1991). Coherence between seasonal cycles of dimethyl sulphide, methanesulphonate and sulphate in marine air. Nature 349 : $404-406$

Barnard, W. R., Andreae, M. O., lverson, R. L. (1984). Dimethylsulfide and Phaeocystis poucheti in the southeastern Bering sea. Cont. Shelf Res. 3: 103-113

Billen, G., Joiris, C., Meyer-Reil, L., Lindeboom, H. (1990). Role of bacteria in the North Sea ecosystem. Neth. J. Sea Res. 26: 265-293

Brimblecombe, P., Shooter, D. (1986). Photo-oxidation of dimethylsulfide in aqueous solution. Mar. Chem. 19: $343-353$

Bürgermeister, S., Georgii, H.-W. (1991). Distribution of methanesulfonate, NSS sulfate and dimethylsulfide over the Atlantic and the North Sea. Atmos. Environ. 25: $587-595$

Cadée, G. C., Hegeman, J. (1986). Seasonal and annual variation in Phaeocystis pouchetii (Haptophyceae) in the westernmost inlet of the Wadden Sea during the 1973 to 1985 period. Neth. J. Sea Res. 20: 29-36

Cantoni, G. L., Anderson, D. G. (1956). Enzymatic cleavage of dimethylpropiothetin by Polysiphonia lanosa. J. biol. Chem. 222: 171-177

Charlson, R. J., Lovelock, J. E., Andreae, M. O., Warren, S. G. (1987). Oceanic phytoplankton, atmospheric sulfur, cloud albedo and climate. Nature 326: 655-661

Cooper, W. J., Matrai, P. A. (1989). Distribution of dimethyl sulfide in the oceans: a review. In: Saltzman, E. S., Cooper, W. J. (eds.) Biogenic sulfur in the environment. American 
Chemical Society Symp. Ser. 393, Washington, DC, p. $140-151$

Dacey, J. W. H., Blough, N. (1987). Hydroxide decomposition of dimethylsulfoniopropionate to form dimethylsulfide. J. geophys. Res. Lett. 14: 1246-1249

Dacey, J. W. H., Wakeham, S. G. (1986). Oceanic dimethylsulfide: production during zooplankton grazing. Science 233: $1314-1316$

Dickson, D. M. J., Kirst, G. O. (1987a). Osmotic adjustment in marine eukaryotic algae: the role of inorganic ions, quaternary ammonium, tertiary sulphonium and carbohydrate solutes. I. Diatoms and a rhodophyte. New Phytol. 106: 645-655

Dickson, D. M. J., Kirst, G.O. (1987b). Osmotic adjustment in marine eukaryotic algae: the role of inorganic ions, quaternary ammonium, tertiary sulphonium and carbohydrate solutes. II. Prasinophytes and haptophytes. New Phytol. 106: $657-666$

Dixon, M., Webb, E. C. (1979). Enzymes, 3rd edn. Longman, London

Fitzgerald, J. W. (1991). Marine aerosols: a review. Atmos Environ. 25: 533-545

Foley, J. A., Taylor, K. E., Ghan, S. J. (1991). Planktonic dimethylsulfide and cloud albedo: an estimate of the feedback response. Clim. Change 18: 1-15

Gibson, J. A. E., Garrick, R. C., Burton, H. R., McTaggart, A. R. (1990). Dimethylsulfide and the alga Phaeocystis pouchetii in antarctic coastal waters. Mar. Biol. 104: $339-346$

Gröne, T., Kirst, G. O. (1992). The effect of nitrogen deficiency, methionine and inhibitors of methionine metabolism on the DMSP contents of Tetraselmis subcordiformis (Stein). Mar. Biol. 112: 497-503

Ishida, $Y$ (1968). Physiological studies on the evolution of dimethylsulfide. Mem. Coll. Agric. Kyoto Univ. 94: 47-82

Karsten, U., Wiencke, C., Kirst, G. O. (1990). The $\beta$-dimethylsulfoniopropionate (DMSP) content of macroalgae from Antarctica and southern Chile. Bot. Mar. 33: 143-146

Keller, M. D., Bellows, W. K., Guillard, R. R. L. (1989) Dimethyl sulfide production in marine phytoplankton. In. Saltzman, E. S., Cooper, W. J. (eds.) Biogenic sulfur in the environment. American Chemical Society Symp. Ser. 393 Washington, DC, p. 167-182

Kelly, D. P., Smith, N. A. (1990). Organic sulfur compounds in the environment: biogeochemistry, microbiology and ecological aspects. In: Marshall, K. C. (ed.) Advances in microbial ecology, Vol. 11. Plenum Press, New York, p. $345-385$

Kiene, R. P. (1990). Dimethylsulfide production from dimethylsulfoniopropionate in coastal seawater samples and bacterial cultures. Appl. environ. Microbiol. 56 3292-3297

Kiene, R. P. (1992) Dynamics of dimethyl sulfide and dimethylsulfonio-propionate in oceanic water samples. Mar. Chem. 37: 29-52

Kiene, R. P., Bates, T. S. (1990). Biological removal of dimethyl sulfide from seawater. Nature 345: 702-705

Kiene, R. P., Service, S. K. (1991). Decomposition of dissolved DMSP and DMS in estuarine waters: dependence on temperature and substrate concentration. Mar. Ecol. Prog. Ser 76: $1-11$

Kirst, G. O. (1989). Salinity tolerance of eukaryotic marine algae. A. Rev. Plant Physiol. Plant Mol. Biol. 40: 21-53
Kirst, G. O., Thiel, C., Wolff, H., Nothnagel, J., Wanzek, M., Ulmke, R. (1991). Dimethylsulfoniopropionate (DMSP) in ice-algae and its possible biological role. Mar. Chem. 35: $381-388$

Liss, P. S., Slater, P. G. (1974\}. Flux of gases across the air-sea interface. Nature 247 $181-184$

Nguyen, B. C., Belviso, S., Mihalopoulos, N., Gostan, J., Nival, P. (1988). Dimethyl sulfide production during natural phytoplankton blooms. Mar. Chem. 24: 133-141

Paul, J. H. (1982). Use of Hoechst dyes 33258 and 33342 for enumeration of attached and planktonic bacteria. Appl. environ. Microbiol. 44: 939-944

Prospero, J. M., Savoie, D. L., Saltzman, E. S., Larsen, R. (1991). Impact of oceanic sources of biogenic sulphur on sulphate aerosol concentrations at Mawson, Antarctica. Nature 350: 221-223

Reed, R. H. (1983). Measurement and osmotic significance of $\beta$-dimethylsulfoniopropionate in marine microalgae. Mar. biol. Lett. 4: 173-178

Schwartz, S. E. (1988). Are global cloud albedo and climate controlled by marine phytoplankton? Nature 336: 441-445

Sieburth, J. M. (1960). Acrylic acid, an 'antibiotic' principle in Phaeocystis blooms in Antarctic waters. Science 132: 676-677

Sieburth, J. M. (1961). Antibiotic properties of acrylic acid, a factor in the gastrointestinal antibiosis of polar marine animals. J. Bacteriol. 82: 72-79

Taylor, B. F., Kiene, R. P. (1989). Microbial metabolism of dimethyl sulfide. In: Saltzman, E. S., Cooper, W. J. (eds.) Biogenic sulfur in the environment. American Chemical Society Symp. Ser. 393, Washington, DC, p. 202-221

Turner, S. M., Malin, G., Liss, P. S., Harbour, D. S., Holligan, P. M. (1988). The seasonal variation of dimethyl-sulfoniopropionate concentrations in near-shore waters. Limnol. Oceanogr. 33: 364-375

Turner, S. M., Malin, G., Liss, P. S. (1989). Dimethyl sulfide and (dimethylsulfonio)propionate in European coastal and shelf waters. In: Saltzman, E. S., Cooper, W. J. (eds.) Biogenic sulfur in the environment. American Chemical Society Symp. Ser. 393, Washington, DC, $p$. $183-200$

Utermöhl, H. (1958). Zur Vervollkommung der quantitativen Phytoplankton Methodik. Mitt. int. Verein. theor. angew. Limnol. 9: 1-38

Vairavamurthy, A., Andreae, M. O., Iverson, R. L. (1985). Biosynthesis of dimethyl sulfide and dimethylpropiothetin by Hymenomonas carterae in relation to sulfur source and salinity variations. Limnol. Oceanogr. 30:59-70

van Boekel, W. H. M., Hansen, F. C., Riegman, R., Bak, R. P. M. (1992). Lysis-induced decline of a Phaeocystis spring bloom and coupling with the microbial foodweb. Mar. Ecol. Prog. Ser 81: 269-276

Veldhuis, M. J. W. Admiradl, W. (1987). The influence of phosphate depletion on the growth and colony formation of Phaeocystis pouchetii (Hariot) Lagerheim. Mar. Biol. 95: $47-54$

Wakeham, S. G., Dacey, J. W. H. (1989). Biogeochemical cycling of dimethyl sulfide in marine environments. In: Saltzman, E. S., Cooper, W. J. (eds.) Biogenic sulfur in the environment. American Chemical Society Symp. Ser. 393, Washington, DC, p. $152=156$

White, R. H. (1982). Analysis of dimethyl sulfonium compounds in marine algae. J. mar. Res. 40: 529-536

Manuscript first received: September 25, 1992

Revised version accepted: February 12, 1993 